\title{
Present Situation, Suggestions on Foreign Exchange Risk Management of Chinese Multinational
}

\author{
Qi Li, \\ School of Economics and Management, Nanjing University of Science and Technology, Nanjing ,210094 , \\ China;
}

763689495@qq.com

Keywords: foreign exchange risk management, Chinese multinational corporations, strategy

\begin{abstract}
In view of the actual situation of foreign exchange risk management of Chinese enterprises, this paper analyzes the problems existing in foreign exchange risk management of enterprises. And on this basis, to elaborate the enterprises to strengthen foreign exchange risk management response measures to improve the foreign exchange risk awareness of foreign enterprises and foreign exchange risk prevention capabilities to maintain the sustained and healthy development of enterprises.
\end{abstract}

\section{Introduction}

With the acceleration of the globalization process, China's international trade and economic exchanges become more and more frequent, the RMB exchange rate shocks increased, any big country's policy options will have foreign exchange risk, these foreign exchange risk will undoubtedly affect its financial performance, strengthen the enterprises' foreign exchange risk management is also increasingly important.

Foreign exchange risk (also known as FX risk, exchange rate risk or currency risk) is a financial risk that exists when a financial transaction is denominated in a currency other than that of the base currency of the company. Foreign exchange risk also exists when the foreign subsidiary of a firm maintains financial statements in a currency other than the reporting currency of the consolidated entity.

\section{Current Situation of Foreign Exchange Risk Management of Chinese Multinational Enterprises}

\subsection{The external environment of foreign exchange risk management of Chinese multinational corporations}

July 21, 2005, China began to implement the market supply and demand as a basis, with reference to a basket of currencies to adjust, managed floating exchange rate system. June 19, 2010, the People's Bank of China decided to "further promote the RMB exchange rate formation mechanism reform, enhance the flexibility of the RMB exchange rate." This shows that the RMB exchange rate has gone to a deeper level of internationalization, and began to market-oriented, so that enterprises face multinational foreign exchange risk than ever before are more complex and more difficult to predict. Foreign exchange risk has become one of the main reasons for changing the operating performance of multinational companies.

\subsection{Foreign exchange risk management of Chinese multinational corporations}

Due to the rapid development of international trade, the foreign exchange business of multinational corporations in China has grown rapidly, but the foreign exchange risk management can not meet the needs of business development, because of the institutional reasons and the "going out" strategy in practice.

\subsubsection{Hidden awareness and ability is not strong}

In China,most of multinational companies in the international business and trade time is short,due to the general lack of foreign exchange risk management awareness and initiative and 
ignoring the foreign exchange risk management, it is difficult to avoid foreign exchange risk. Some multinational companies believe that foreign exchange risk management business in the multinational companies can increase the operating costs, and can not bring profits. The value of exchange rate risk management is ignored by multinational companies, and the necessity of foreign exchange risk management for multinational companies is difficult to be reflected. In addition, multinational companies ignore the summary of foreign exchange risk management, can not improve foreign exchange risk management, and therefore can only continue to suffer foreign exchange risk losses.

\subsection{2 lack of a complete foreign exchange risk management monitoring system}

In our country ,most of multinational companies do not have a relatively complete foreign exchange risk management system. Multinational companies do not have an independent and professional agency responsible for foreign exchange risk management. In the actual operation of multinational companies in China, foreign exchange business is often part-time by other staff, and no professional international financial talent team is responsible for this part of the business. Multinational financial staff do not have the system of foreign exchange knowledge and effective foreign exchange business skills, can not use effective means to hedge foreign exchange risk, so the exchange rate fluctuations in the increasingly dramatic changes can not be adapted. In China, the foreign exchange risk of transnational corporations lacks effective monitoring system, can not effectively identify the foreign exchange risks faced by the company, nor can the foreign exchange risk be managed, forecasted and measured.

\subsection{3 lack of mature foreign exchange risk management tools}

First of all, in the calculation of foreign exchange risk, did not fully consider the use of corporate financial statements and related accounting information to decompose, quantify foreign exchange risk systematically and comprehensive, resulting in the choice of foreign exchange risk management methods lack of comprehensive, systematic and accurate measurement basis.

Second, in the choice of foreign exchange risk management methods, these enterprises are more focused on the use of capital markets and financial instruments, and often ignore the establishment of a sound foreign exchange risk control system. Of course, this is related to the lack of a comprehensive, systematic and accurate measurement system.

When faced with foreign exchange risk, China's multinational corporations is difficult to avoid foreign exchange risk, but also difficult to do a whole overall arrangements of foreign exchange risk.

\subsection{4 professional foreign exchange talent shortage}

Many enterprises in China employ financial staff to manage foreign exchange, and the general financial staff often do not have the ability to forecast and prevent foreign exchange risk, lack of sufficient knowledge of foreign exchange management, therefore, even if the management attaches importance to the management of foreign exchange risk, but because of the lack of professional of foreign exchange personnel and make the management of foreign exchange risk can not be implemented.

\section{Suggestions on Strengthening Foreign Exchange Risk Management of Chinese Multinational Enterprises}

\subsection{To strengthen foreign exchange risk management awareness, effectively avoid foreign exchange risk}

Facing the increasingly complex market environment, strengthening the awareness of foreign exchange risk management is an important prerequisite for science to avoid foreign exchange risk. First of all, enterprises should be aware of the importance and the necessity of foreign exchange risk management.In the subjective initiative, enterprises can actively respond to fluctuations in the RMB exchange rate in order to take timely and effective measures; Second, do publicity and education work well, and strengthen the understanding of foreign exchange risk from top to bottom, to achieve the upper and lower linkage, from top to bottom to deal with a good business environment. Through the improvement of foreign exchange risk management awareness, 
enterprises in business development can better cope with foreign exchange risk.

\subsection{Establish and improve the foreign exchange risk management laws and regulations}

In order to better promote the development of foreign exchange market, strengthen the foreign exchange risk management, establish and improve the foreign exchange risk management laws and regulations show a significant necessity.

First of all, China currently in the field of foreign exchange risk management is more macro-oriented, which requires the development of more specific and detailed management rules, under good operability, regulate the foreign exchange market sustainable development; Second, the state should strengthen the relevant areas of legislation, especially in the futures and trust legislation, which for the sound foreign exchange risk management system plays an important role.In this way, not only help to promote the standardization of foreign exchange market development, but also to ensure that the enterprise foreign exchange risk management has a legal basis.

\subsection{Increase the reserves of foreign exchange risk management specialists}

Only a large number of specialized personnel reserves and use can do foreign exchange risk management well. Now, because of the different structure of knowledge, financial staff in the foreign exchange risk management in the face of specialized problems seem powerless. China lacks professional international financial talents, there is a wealth of practical experience of senior management talent is particularly scarce. Therefore, it is imperative to speed up the attracting and reserve talents and establish and improve the foreign exchange risk management system.

\subsection{Strengthen foreign exchange risk management within the enterprise}

Establish and improve the internal foreign exchange risk management system, determine the duration of the plan, so that the foreign exchange risk management plan and business management plan cycle to match. Speed up the adjustment of enterprise production marketing strategy;To forecast the trend of foreign exchange, including the direction of foreign exchange changes, the time and magnitude, but the exchange rate forecast may be erroneous, to be as accurate as possible; To assess the risk of foreign exchange risk, according to the impact of foreign exchange risk, the foreign exchange risk is divided into primary and secondary risks, to avoid the main to the time, to take appropriate measures to avoid.Specifically include the following two aspects:

(1) to establish a sound foreign exchange risk management department, with specialized foreign exchange management staff and regular training of staff. Improve the company in the management model, organizational structure, risk assessment, implementation steps and other forms of institutional system.

(2) Establish and improve the foreign exchange risk management system, including the identification of foreign exchange risk, the choice of different types of risk measurement and management tools and the subsequent risk management assessment system, the foreign exchange risk losses caused by the minimum control.

\subsection{Make full use of the unique financial methods of multinational corporations}

The production and operation of transnational corporations is carried out under the guidance of its global strategy, so that the risk management of foreign exchange transactions of transnational enterprises is peculiar. As multinational companies within the professional division of labor and the continuous of cooperation deepening, multinational companies also exist in internal transactions and external transactions. Therefore, in addition to the general business of foreign exchange risk management tools, there have been many general enterprises do not have a new way to control foreign exchange risk, such as netting, matching management and advance or deferred settlement.Internal control strategy by managing the risk of foreign exchange trading as an integral part of the day-to-day financial management of an enterprise, it is a way to minimize or prevent the occurrence of exposed net foreign exchange and thus reduce the risk of foreign exchange. Multinationals may also consider using internal controls to reduce foreign exchange risk when uncertain foreign exchange risk, uncertainty about foreign exchange markets, or high hedging costs.

\section{Conclusion}

China's multinational corporations are faced with foreign exchange risk that can not be ignored. 
To maintain their own competitiveness and effectively deal with foreign exchange risks, enterprises must strengthen foreign exchange risk management, raise awareness from the start, adjust the development strategy and solve the problems of foreign exchange risk management system. From the reality of the enterprise, develop a sound management system, ease the exchange rate changes. At the same time, the government should also strengthen foreign exchange risk management policies and laws, and create a favorable foreign exchange risk management environment.

\section{References}

[1] Akihiro Kubo. The macroeconomic impact of foreign exchange intervention: An empirical study of Thailand[J]. International Review of Economics \& Finance, 2017, 49(5):243-254.

[2] Tom Aabo,Marianna Andryeyeva Hansen,Christos Pantzalis. Corporate foreign exchange speculation and integrated risk management[J]. Managerial finance, 2012, 38(8).

[3] Timo Korkeamaki,Danielle Xu. Institutional Investors and Foreign Exchange Risk[J]. The quarterly journal of finance, 2015, 5(3).

[4] Victoria Yun Zhou,Peijie Wang. Managing foreign exchange risk with derivatives in UK non-financial firms[J]. International review of financial analysis, 2013, 29(9): 294-302.

[5] Lukas Menkhoff,Lucio Sarno,Mail Schmeling,Andreas Schrimpf. Carry Trades and Global Foreign Exchange Volatility[J]. Journal of finance, 2012, 67(2):681-718.

[6] Chiara Banti, Kate Phylaktis, Lucio Sarno. Global liquidity risk in the foreign exchange market[J]. Journal of International Money and Finance, 2012, 31:267-291.

[7] Yacine Belghitar, Ephraim Clark,Salma Mefteh. Foreign currency derivative use and shareholder value[J]. International Review of Financial Analysis, 2013, 29:283-293. 